\title{
THIS IS NOT A FESTSCHRIFT
}

This issue is dedicated to Michael Clyne, an outstanding scholar, colleague, mentor, teacher, and friend. Around the time of Michael's retirement in 2004, it was natural for his colleagues to think of compiling a Festschrift in his honour. It was equally natural for Michael, in his modesty, to gently nip the idea in the bud, not wanting to make such an imposition on others. Those who know Michael and his work would quickly realise that to ask even Michael's closest colleagues and friends for short contributions to a Festschrift would mean a number of tomes, compared to which Grimm's Wörterbuch would be a minor undertaking. This is therefore not a Festschrift; if it were, it would be an extension of the genre, since Michael is in fact making a contribution himself, unaware of the aim of dedicating this issue to him. For a sense of the high esteem in which Michael is held both nationally and internationally, we direct the reader to the tributes paid to him (http://www.rumaccc.unimelb.edu.au/clyne/tribute.pdf).

Michael's return in 2001 to his Alma Mater, the University of Melbourne, resulted in the establishment of the Research Unit for Multilingual and Cross-Cultural Communication, and also gave sociolinguistic research at the University a new focus, bringing together colleagues from the School of Languages in an ARC-funded project on Address in some western European languages. This project is a typical example of the initiatives that Michael started and carried through with his characteristic blend of inspiration, enthusiasm for intellectual enquiry, and collegiality. His field-shaping contributions to sociolinguistics are so plentiful that a bibliographical search in almost any area will usually reveal that Michael has already written the seminal work.

Michael has worked in sociolinguistics and German linguistics for many years, and it is rather fitting to end with the following, from the Austrian television series Inspector Rex. For those of you not familiar with the series, Inspector Rex is a German shepherd who assists the police in solving crime. A recent episode ended with the forensic pathologist, Herr Dr. Graf, turning up to his surprise $60^{\text {th }}$ birthday party. Dr. Graf is toasted with champagne by his colleagues of many years, and being the senior colleague, invites everyone to shift to $d u$ and first names. When Rex comes up to offer his congratulations, a bouquet of flowers in his mouth, Dr. Graf leans down and says: 'Of course, you and I, Rex, have always been on $d u$ terms.'

Heinz L. Kretzenbacher, Catrin Norrby and Jane Warren The University of Melbourne 